\title{
FOREIGN TRADE IN ENVIRONMENTAL GOODS IN THE CZECH REPUBLIC (1993 - 2002)
}

\author{
Eva TOŠOVSKÁ *
}

\begin{abstract}
:
This paper analyses the trade flows and tariff rates of environmental goods in the Czech Republic in the period $1993-2002$. The analysis is based on environmental goods' categories according to "OECD list of environmental goods". The export and import of environmental goods is investigated also from the foreign trade territorial structure point of view. The five indicators have been used to describe the achieved level of trade liberalization in environmental goods in the Czech Republic.
\end{abstract}

Keywords: environmental goods, imports of environmental goods, exports of environmental goods, environmental goods customs tariffs

JEL Classification: F13, L60

\section{Introduction}

The growing significance attributed to the environmental protection and sustainable development strategy, both in advanced and developing countries, has been a cause of an increasing focus of separate countries on trade in the goods that may contribute to the environmental protection and efficient utilization of natural resources. The dynamic nature of the environmental goods sector, together with its potential for strengthening environmental protection, made it an obvious candidate for a trade liberalization initiative, one that could both improve the environment and boost international trade. The issues have unavoidably found their way to the agenda of multilateral trade negotiations within the World Trade Organization (WTO), both within a wider context of talks on continued liberalization of access for non-agricultural products to the markets and the context of negotiations for possible reductions

*) Economics Institute of the Academy of Sciences of the CR, Politických vězňů 7, CZ - 11121 Prague 1 (e-mail:eva.tosovska@ cerge-ei.cz). 
of tariff and non-tariff barriers to trade in environmental goods (see the Doha Ministerial Declaration, paragraph 31(iii)).

In general terms, environmental goods include those that "measure, prevent, limit, minimise or correct environmental damage to water, air and soil, as well as problems related to waste, noise and eco-systems, including cleaner technologies, products and services that reduce environmental risk and minimise pollution and resource use" (see The Environmental Goods..., 1999). "Environmental goods" were not further defined in the Doha Declaration. However, a substantial amount of work to identify the scope of environmental goods has already been undertaken by the OECD and APEC (Asia/Pacific Economic Cooperation), culminating in two product lists of candidate goods (see Environmental Goods..., 2003).

This analysis brings part of the solution under the grant ref. No. A7085201 "Environmental Assessment of Czech Trade Policies" of the Grant Agency of the Czech Academy of Sciences. The purpose has been to set up a database enabling description of the trade flows and tariff burden on environmental goods in the Czech Republic.

The analysis is based on environmental goods' categories with harmonised commodity description and coding system according to the OECD (see Environmental Goods and Services..., 2001). The OECD list covers up the environmental goods serving to air pollution control, waste water management, solid waste management, remediation and clean-up, noise and vibration abatement and environmental monitoring, analysis and assessment. Data related to exports, imports, per-kilogram prices, net weight and tariff rates have been assigned to each of the 161 rows of the OECD environmental goods list.

\section{Imports of Environmental Goods to the Czech Republic in the Period $1993-2002$}

In accordance with the requirements of the environmental protection legislation (above all the deadlines for meeting relevant limits and standards), the interest on the part of both the governmental and corporate sectors in environmental goods (EG) kept on growing over the period under review. That was reflected in a continuous growth of imports of this type of goods. ${ }^{1)}$ While the total imports of EG amoun-

Figure 1

Import of Environmental Goods (in \%, $1993=100)$

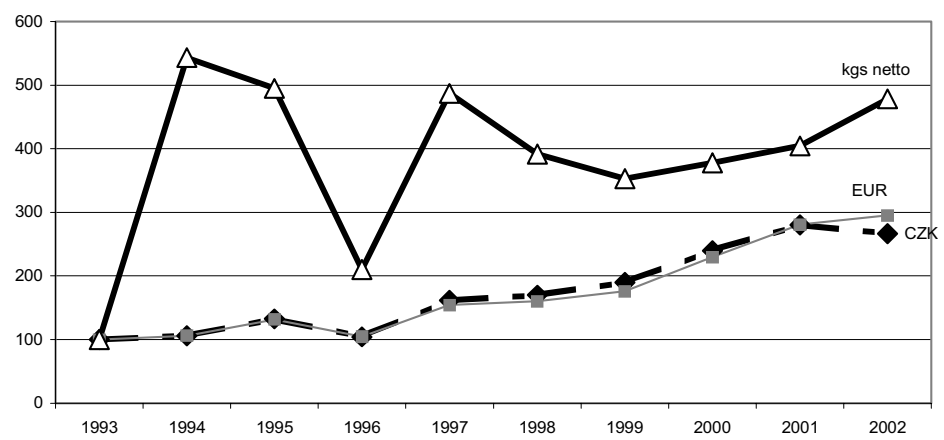

Source: Based on the data of Statistical Department, Ministry of Industry and Trade of the CR.

1) With an exception in 1996 and a minor decrease in 2002. 
ted to CZK 31.600 mill. in 1993, they increased to CZK 84.223 mill. in 2002 (i.e. by $166 \%$ ). The volume of the environmental goods imports presented $6.4 \%$ in the overall Czech imports in 2002. The growth dynamics of the EG overall imports was even more pronounced in net kilograms than in monetary terms, having recorded an increase by $378 \%$ as compared to 1993 .

The EG import structure viewed in value terms shows that, across all the years under review, the largest share has been achieved by the goods related to waste water management (A2) (42.8\% in 2002). ${ }^{2)}$ This type of goods has also won the largest share in the overall EG imports in terms of net weight in kilograms $(51.4 \%$ in 2002). Within this group of goods, the largest share has been held by various types of pumps, compressors, water filtering and purification devices, cocks and fittings for piping, and plastic products. They have mostly involved items directly or vicariously related to construction of the waste water treatment plants, i.e. traditional end of pipe technologies. While construction of the largest waste water treatment plants was completed in the Czech Republic around 2000, a considerable space for imports has been anyway left in this area.

Figure 2

Import of Environmental Goods (from data in EUR)

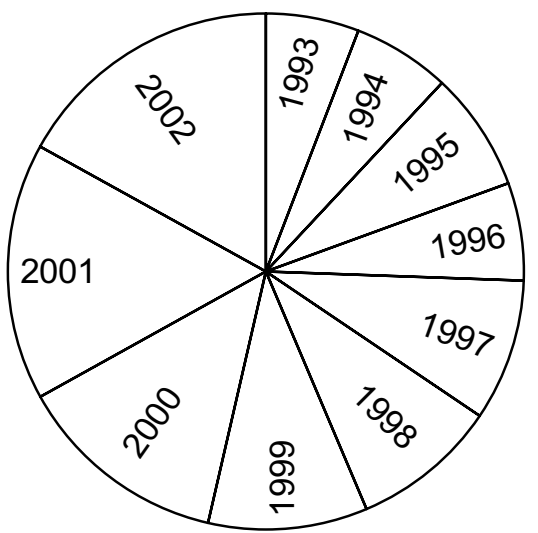

Source: Based on the data of Statistical Department, Ministry of Industry and Trade of the CR.

The rate of efficiency of a significant proportion of the operating large waste water treatment plants in the Czech Republic is insufficient and they are not equipped with the stage for removal of nitrogen and phosphorus. There are still several dozens of municipalities within the population size category from 2,000 to 10,000 that lack any waste water treatment plant or a connection to the group waste water treatment plant. ${ }^{3)}$

Numerous problems with purification of the waste water survive also in certain industries, although volumes of the waste water discharged into the surface water by industrial facilities have decreased quite significantly. Certain paper industry plants still purify the waste water in biological purifying plants only, which provides a space for imports of equipment enabling construction of the tertiary purification stage. Certain chemical plants discharge special pollutants (such as AOX - adsor-

2) The only exception has been represented by the year 1996 in which the largest volume was reached by the imports of goods for air pollution control.

3) The CR successfully negotiated an interim period in this area during the EU pre-accession negotiations. 
Figure 3

Import of Environmental Goods (share in \% from data in CZK)

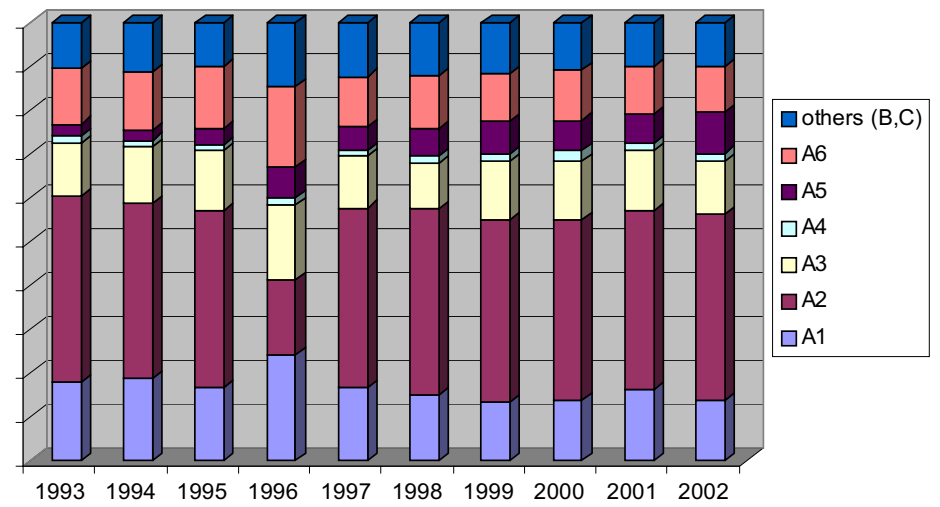

A1 air pollution control

A2 waste water management

A3 solid waste management

A4 remediation and clean-up

A5 noise and vibration abatement

A6 environmental monitoring, analyses etc.

Others $(\mathrm{B}, \mathrm{C})$

Source: Based on the data of Statistical Department, Ministry of Industry and Trade of the CR.

bable organic halides, heavy metals) in the surface water that the current purifying plants are unable to entrap. The demand for imports of sophisticated systems or their components may be expected in this area. Also certain food industry plants are faced with a necessity to move to a higher than just the mechanical and biological purification stages. Further, numerous textiles and leather industry plants are in an urgent need of improving the efficiency of waste water treatment plants.

New quality of requirements concerning the EG imports in A2 group may be expected due to the requirements of the integrated pollution prevention and control (or, based on a comparison of the technologies in use with the Best Available Technologies).

The second position in the imports of EG, at a considerable distance, is held by the air pollution control goods (A1). This group had in the total EG imports the share of $13.7 \%$ in 2002, in value terms, and even $29.3 \%$ in net weight in kilograms. Almost three quarters of the imports consisted in compressors, exhausters, cooling equipment and devices for gas filtering and purification.

Further requirements for imports of the equipment for improving the air quality will ensue from the binding import terms and conditions, specifically from the pollutant emission limits imposed by the new Air Protection Act (as of June 2002). A specific role will be played by the requirements of the integrated pollution prevention and control (IPPC) and the emphasis on the Best Available Technologies. The interest will grow mainly in low emission, low refuse and energy saving technologies and closed production cycles. It will be urgently necessary to ensure, through imports or local production, implementation of measures for the improved quality of the air in regions with the deteriorated quality of the air. 
A somewhat lower share, compared to the air pollution control goods, in the total EG imports is held by the solid waste management related goods (A3). The share, in value terms, amounted to $12.0 \%$ in 2002 (and the largest share of $17 \%$ was achieved in 1996). The solid waste management goods, however, had only a very little share in the overall EG imports expressed in kilograms (only $3.9 \%$ in 2002). Within A3 group imports, an almost $80 \%$ share is held by various mechanical instruments with an individual function; non-reinforced polymer and propylene boards; and electrical industrial furnaces, including induction ones and their parts.

The waste disposal in the Czech Republic continues to represent an open space for potential imports. New requirements on improved sophistication of the waste disposal will undoubtedly arise from the country's regional waste disposal policies that have been currently drafted based on the Waste Disposal Policy for the Czech Republic. While the Czech Republic has been comparatively sufficiently equipped with the waste site facilities, an increased demand for contemporary incinerating plants or their components may be envisaged. The now existent refuse incinerating plants are not equipped with all required stages (such as for entrapping dioxins) and even some of the dangerous waste incinerating plants fail to comply with the emission limits in force. Totally lacking in the Czech Republic are modern facilities serving more suitable disposal of waste, specifically facilities for processing the biologically decomposable proportion of the communal refuse dumped at the waste sites, and facilities for reclamation of materials from the refuse prior to its energy generation use. Within this EG group, the import demand may arise also due to the more efficient disposal of used oils, PCB, used batteries and accumulators, fluorescent tubes etc.

Environmental goods imports increased by $166 \%$ in 2002 compared to 1993, while a truly extreme growth drive was recorded by the noise and vibration abatement goods (A5) (increase by $828 \%$ ). The share in the total EG imports of this group is more than $9 \%$ in value terms, and only $2.3 \%$ in terms of kilograms. The largest importers within this EG group include Italy, Germany and Poland. In view of the fact that, according to the most recent measurements, only a minor part of locations is fully compliant with the requirements of the Czech Government Ordinance No. 502/2000, on Health Protection against Adverse Effects of Noise and Vibrations, a continued interest may be expected in imports of the equipment reducing the noise emissions. The key focus will be the machinery and technologies with low levels of the noise emission values, both in the construction industry and certain industrial operations.

A stable, over $10 \%$, share in value terms in the EG structure has been maintained by the goods related to environmental monitoring, analyses and valuation (A6). This group's share in the EG imports in net weight terms is, however, negligible $(0.2 \%)$. It includes mainly automatic regulation and control instruments, thermostats and instruments for measuring features of liquids and control of gases. The largest importers include Germany, the U.S. and U.K. Further demand for imports of this EG group may be expected mainly resultant to stricter requirements for the monitoring quality in integrated prevention and pollution reduction. Considerable gaps can also be found in biomonitoring in the Czech Republic.

The products classified under B2, cleaner products, in the OECD EG list are very limited in number. Correspondingly, there is only a small share of $3 \%$ of this group in the structure of the EG imports in the Czech Republic. Notwithstanding the fact that the "Cleaner Production Programme" used to rank among the highly preferred programmes from 1998 on, supported also by the State Environmental Fund of the Czech Republic. ${ }^{4)}$

4) The program has been replaced with the Best Available Technologies Programme since 2000. 
The goods classified under C2 group, water supply, while contributing quite negligibly to the total EG imports in value terms $(0.3 \%)$ nevertheless represent the goods of considerable net weight in kilograms (the latter's share in C2 was recorded at $6 \%$ in 2002, and even at $12.6 \%$ in 2000). The major share of $65 \%$ in the C2 imports is held by mineral waters, carbonated waters and other sweetener-free waters. These have been imported into the Czech Republic mostly from Slovakia, France and Poland.

Another marginally sharing group in the overall EG imports is represented by the items falling under the $\mathrm{C} 4$ category, representing products utilisable in power stations based on the renewable resources (1.6\% in value terms and $3.7 \%$ in kilograms in 2002). The largest importers include Germany, Russia and China. The import potential of this type of goods is due to the fact that the "green" energy generation in the Czech Republic should increase from the current $1.5 \%$ to $6 \%$ by 2005 (and to $11 \%$ by 2030$){ }^{5)}$

It follows from the international comparison of the energy intensiveness per GDP unit that a considerable energy savings potential exists in the Czech Republic. In accordance with the governmental energy savings programme, further growth may be envisaged in imports of the goods enhancing heat and energy savings (C5). Their current share in the EG imports is only $5 \%$ in value terms. A dominant position on the market is still maintained by importers from Germany, Italy and Sweden, and, for transition economies, from Slovakia and Poland.

Territorial structure of the environmental goods imports. Tendencies in the territorial structure of the environmental goods imports are identical to those in the overall Czech imports in the last ten years. They are marked by a total divergence from the Eastern markets and orientation at imports from the advanced countries, specifically from the EU. Germany is clearly the largest importer of environmental goods, the same as in case of the overall imports in the Czech Republic, for all categories - air protection goods, surface water protection or waste disposal. Germany has the share of approx. $40 \%$ in the imports of the above most important EG groups.

Table 1

Overview of Largest Importers of Environmental Goods in the Czech Republic in 2002 (in CZK 000)

\begin{tabular}{|l|r|l|r|l|c|}
\hline Air control goods & $\%$ & $\begin{array}{l}\text { Waste water } \\
\text { management goods }\end{array}$ & $\%$ & $\begin{array}{l}\text { Solid waste } \\
\text { management goods }\end{array}$ & $\%$ \\
\hline Total imports $11,508,714$ & 100 & Total $36,033,496$ & 100 & Total 10,101,555 & 100 \\
\hline of which: & 37.6 & Germany & 44.3 & Germany & 40.0 \\
\hline Germany & 5.8 & Italy & 8.9 & Italy & 9.6 \\
\hline France & 5.2 & Austria & 5.6 & Japan & 8.9 \\
\hline $\begin{array}{l}\text { England and Northern } \\
\text { Ireland }\end{array}$ & 4.7 & France & 5.2 & Slovakia & 5.5 \\
\hline Austria & 4.4 & U.S. & 4.4 & France & 5.3 \\
\hline Spain & & & \\
\hline
\end{tabular}

Source: Calculation based on data of Statistical Department, Ministry of Industry and Trade of the CR.

5) The Czech Ministry of Environment requires $20 \%$. 
It is obvious from the Table 1 that imports by the five largest suppliers amount to almost $60 \%$ for the air protection goods and to almost $70 \%$ for the waste water management and solid waste goods. The table further reveals an above-the-average share of Germany in imports of environmental goods in the Czech Republic for all groups and, consequently, a high-degree dependency of the Czech Republic with regard to this segment on the economic development in Germany and its possible fluctuations.

The scant share of environmental goods imports from the former Soviet Union countries (it amounted to CZK 334,81 bill. in 2002 and represented a share of only $0.4 \%$ in the total EG imports) may be attributed to the consequences of the Soviet market collapse in the beginning of the 1990s (and the Comecon disintegration). While this import in value terms increased by $127 \%$ as compared to 1993 , its share in the total EG imports remained the same. From transition economies, only Slovakia records a significant share in EG imports to the Czech Republic (see its share in the solid waste disposal goods) and, in the same market segment, also Poland (with its share of $4.7 \%$ in imports of the solid waste disposal goods it ranks right after France).

In 1993, imports of environmental goods from developing countries in the Czech Republic were practically negligible $(0.3 \%)$, and while this share grew more than sixfold in 2002, these imports' amount is still very low (1.9\%). In 2002, developing countries' share was less than $2 \%$ in the overall EG imports in the Czech Republic (which amount to over CZK 84 mill.). The fact that the number of developing countries with whom the Czech Republic maintains trade relations more than doubled over the period from 1993 to 2002 has been most beneficial from the view of further increasing potential business contacts with the developing countries in the environmental goods area.

The Czech market is described by a high-degree of openness towards imports of environmental goods from developing countries. Typical of this openness are namely low rates of customs tariffs for all groups of environmental goods (see Chapter 4 for details). Technological, as well as any sanitation and phytosanitation measures are notified by the Czech Republic with the WTO in line with the standard procedures. ${ }^{6)}$ Given the fact that notifications have stemmed out from harmonisation of the Czech technological regulations and standards with the relevant EU standards, the non-tariff barriers area represents rather an improved level of transparency of the trade "landscape" for the potential exporters from developing countries.

\section{Exports of Environmental Goods from the Czech Republic from 1993 to 2002}

The Czech Republic is also a significant exporter of environmental goods. EG exports kept on growing without a single fluctuation over the period under review despite disintegration of the traditional Eastern markets and the necessity of looking for new markets, economic transformation in progress and privatization of most of the businesses. These exports have the share of $5.1 \%$ in the overall Czech exports in 2002. While they amounted to CZK 18.33 bill. in 1993, they increased to CZK 63.88 bill. (i.e. by $248.5 \%$ ) by 2002 . EG exports in terms of net weight in kilograms were moving along a similar trend (the growth by $254 \%$ ).

6) In 2002, for example, the Czech Republic filed 42 notifications with the WTO in accordance with the Agreement on Technical Barriers to Trade, out of which 11 were motivated by environmental protection. Most of them related to air protection. 
Figure 4

Export of Environmental Goods (in \%, $1993=100$ )

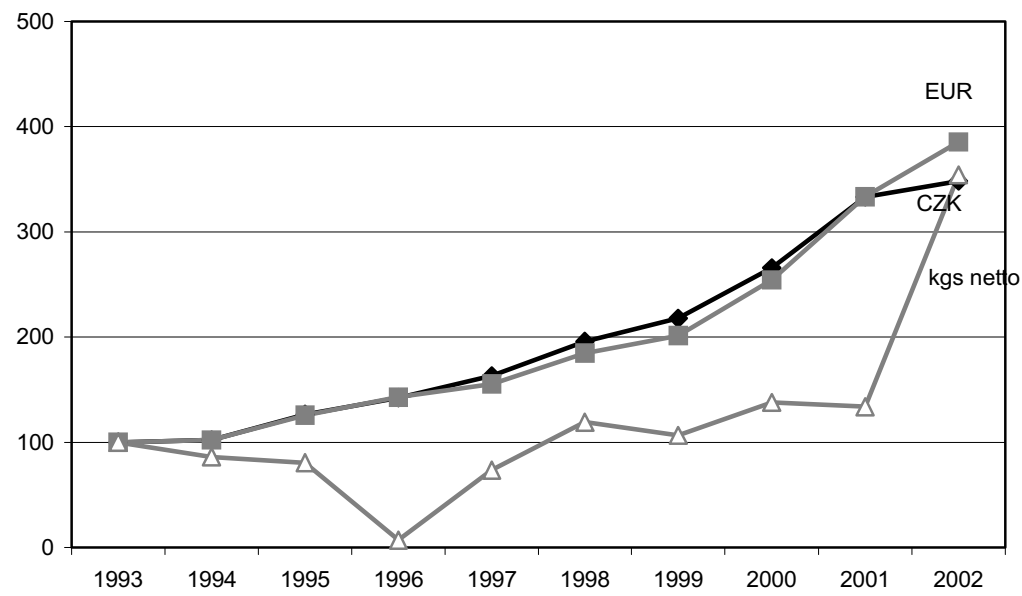

Source: Based on the data of Statistical Department, Ministry of Industry and Trade of the CR.

Figure 5

Export of Environmental Goods (from data in EUR)

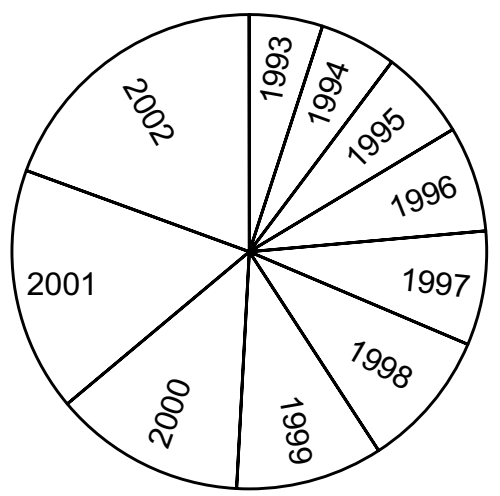

Source: Based on the data of Statistical Department, Ministry of Industry and Trade of the CR.

The largest share in the overall EG exports in terms of value has been maintained by the waste water management goods throughout all the years. It was achieved mainly thanks to the exports of plastics, cocks and fittings for piping, and turbine and waterwheel parts. Exports of the goods culminated in the periods of 1996 and 1997 (the average share of $53.8 \%$ ), followed by a moderate drop (43.4\% in 2002).

A stable, more than $12 \%$ share has been maintained by the air pollution control goods. The Czech Republic was exporting mainly instruments for filtration and purification of gases; parts of vacuum pumps, compressors and ventilators; and exhausters in this segment. 
Approximately a $10 \%$ share in the total EG exports has been maintained by the solid waste disposal goods. In 2002, these exports involved mostly various mechanical machines with individual functions, as well as components of industrial and laboratory furnaces. Within this group of goods, the highest per-kilo price in CZK was achieved at the exports of lasers.

Quite an extraordinary dynamics was recorded by exports of the noise and vibration abatement goods (increased by $913 \%$ from 1993 to 2002) that ranked, thanks to their $20 \%$ share in the total EG exports in 2002, next behind the waste water management goods. Exports of the environmental monitoring instruments increased by $204 \%$ from 1993 to 2002, however, their share in the EG exports has been below $6 \%$.

The Czech Republic has been so far unsuccessful in penetrating the market for the goods for power plants based on renewable resources $(1.1 \%$ share in CZK in the exports) and a potential for increasing exports is present also in the goods supporting heat and energies savings (currently $5 \%$ ).

Figure 6

Export of Environmental Goods (share in \% from data in CZK)

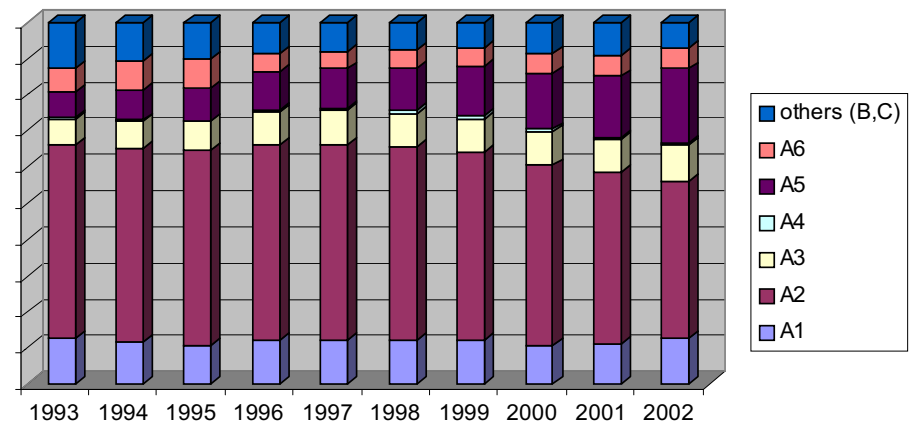

Source: Based on the data of Statistical Department, Ministry of Industry and Trade of the CR.

We get an utterly different picture, though, when assessing the EG exports structure in terms of net weight in kilograms. In the overall weight of the EG exports, potable water supply and distribution (sub-group C2) share is $75 \%$, involving specifically exports of sweetener-free and aroma-free waters, including ice. These goods achieve the lowest price per kilo (CZK 0.02).

Territorial structure of the environmental goods exports. The territorial structure of the environmental goods exports is not significantly different from that of the EG imports. Here, too, a high degree integration of the Czech economy within the West European markets gets revealed. Clearly dominant in the EG exports are the advanced market economy countries, including also the EU countries, with an overwhelming majority held by Germany. The sequence of countries into which the Czech Republic has been exporting the largest amounts of the goods falling under the three largest EG groups, is provided by the below table.

Germany is an unrivalled customer of the Czech Republic for the EG. The range of the other customers is more colourful as it involves not only the EU-15 Members and transition economies, but also Norway and Turkey as yet another relevant target countries for the Czech EG exports. 
Table 2

Countries to which the Czech Republic Exported the Largest Volumes of Environmental Goods in 2002 (in CZK 000)

\begin{tabular}{|l|r|l|r|l|r|}
\hline Air pollution control goods & $\%$ & $\begin{array}{l}\text { Waste water } \\
\text { management goods }\end{array}$ & $\%$ & $\begin{array}{l}\text { Solid waste } \\
\text { management goods }\end{array}$ & $\%$ \\
\hline Total exports 8,067,618 & 100 & Total 27,751,087 & 100 & Total 6,415,443 & 100 \\
\hline of which: & & & & & \\
\hline Germany & 41.5 & Germany & 43.5 & Germany & 40.8 \\
\hline Turkey & 9.9 & France & 3.7 & Norway & 9.2 \\
\hline Slovakia & 7.2 & Italy & 3.4 & Slovakia & 7.6 \\
\hline Norway & 7.1 & Austria & 3.3 & Poland & 5.3 \\
\hline France & 5.2 & Netherlands & 3.0 & France & 4.6 \\
\hline
\end{tabular}
CR.

Source: Calculation based on the data of Statistical Department, Ministry of Industry and Trade of the

Exports of environmental goods of all groups into the former Soviet Union countries amounted to CZK 2.21 bill. in 1993 and has a share of approx. $12 \%$ in the overall EG exports. These exports, in terms of value, practically stagnated (increased by $14 \%$ ) in 2002, while the share in the total EG exports dropped to $4 \%$. Most of the goods exported into the former Soviet Union countries included the remediation and clean-up and environmental monitoring goods.

The dynamics of environmental goods exports by the Czech Republic to the developing countries (increased by $37 \%$ from 1993 to 2002) has been lagging distinctly behind the overall EG exports dynamics (increase by $248 \%$ ). The share of developing countries in the total EG exports at only $1.7 \%$ cannot be deemed satisfactory.

The Czech Republic exports the most of the air pollution control goods to Brazil and Iran, and waste water management goods to Iran, Saudi Arabia and India. The largest customers for the solid waste disposal goods manufactured in the Czech Republic include Malaysia, Thailand, Iran and Morocco.

Further developments of the environmental goods exports from the Czech Republic to the developing countries may be significantly enhanced by the fact that the Czech Republic has established business contacts in separate EG market segments with many of these countries (e.g. it includes 74 countries in relation to trading in the waste water management goods).

If we leave aside the obstacles generally hindering the development of the EG exports on the part of the Czech companies, ${ }^{7)}$ an important role is played by the comparatively high customs tariffs for environmental goods in force in separate developing countries.

7) For details, see "Identifying Complementary Measures to Ensure the Maximum Realization of Benefits from the Liberalization of Trade in Environmental Goods and Services, Case Study: Czech Republic. Paris, OECD, May 2003. 


\section{Foreign Trade Balance in Environmental Goods in the Czech Republic}

The Czech Republic's foreign trade balance in environmental goods has been negative over all of the years under review (1993-2002). The largest negative balance (more than CZK 27 bill.) resulted in 2000 and 2001. The factors with significant bearing upon the development of export and import EG prices in CZK included also the Czech koruna exchange rate changes. ${ }^{8)}$

Figure 7

Foreign Trade in Environmental Goods (in CZK mill.)

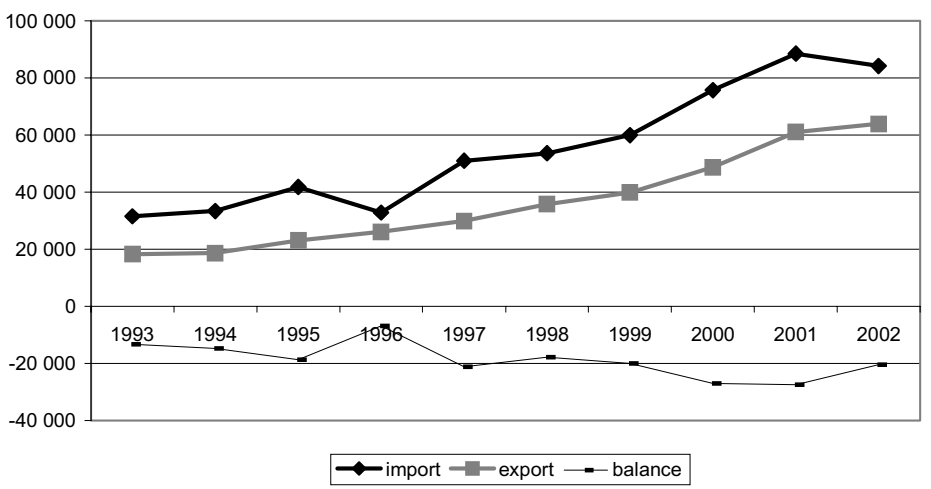

Source: Based on the data of Statistical Department, Ministry of Industry and Trade of the CR.

In addition to the data in monetary terms, environmental goods exports and imports may be compared also in terms of net weight in kilograms.

Table 3

Imports, Exports and Foreign Trade Balance in Environmental Goods in the Czech Republic (in CZK mill.)

\begin{tabular}{|l|c|c|c|c|c|c|c|c|c|c|}
\hline & 1993 & 1994 & 1995 & 1996 & 1997 & 1998 & 1999 & 2000 & 2001 & 2002 \\
\hline Imports & 31.601 & 33.444 & 41.861 & 32.871 & 51.060 & 53.628 & 59.992 & 75.741 & 88.550 & 84.223 \\
\hline Exports & 18.328 & 18.706 & 23.199 & 26.105 & 29.882 & 35.897 & 39.938 & 48.713 & 61.101 & 63.884 \\
\hline Balance & -13.272 & -14.737 & -18.661 & -6.766 & -21.177 & -17.731 & -20.054 & -27.027 & -27.448 & -20.338 \\
\hline
\end{tabular}

Source: Data of Statistical Department, the Ministry of Industry and Trade of the CR.

8) The Czech koruna (CZK) exchange rate fluctuated considerably from 1999 to the beginning of 2001. The overall tendency of the koruna's nominal rate resulted from the currency's gross depreciation relating to USD and appreciation to EUR (see Nešvera, Kubišta, 2001). 
Table 4

Comparison of Net Weight $(\mathrm{kg})$ Exports and Imports of Environmental Goods in the Czech Republic

\begin{tabular}{|l|r|r|r|r|r|r|r|r|r|r|}
\hline & 1993 & 1994 & 1995 & 1996 & 1997 & 1998 & 1999 & 2000 & 2001 & 2002 \\
\hline Exports & 173 & 60 & 62 & 124 & 57 & 116 & 115 & 139 & 126 & 282 \\
\hline Imports & 100 & 100 & 100 & 100 & 100 & 100 & 100 & 100 & 100 & 100 \\
\hline
\end{tabular}

Source: Data of Statistical Department, the Ministry of Industry and Trade of the CR.

The data in the Table 4 show that the EG exports weight exceeded, during the major part of the period under review (except for three years), the same indicator for the EG imports (in spite of the fact that the import volumes were considerable higher). The growth of the EG net weight recorded over the recent years should be deemed an unfavourable trend.

Imports and exports in separate groups of environmental goods may be compared also in terms of their prices per kilogram. The higher the relevant indicator, the higher is the technical or technological level of the respective environmental goods or the more consuming has been its research and development, etc.

Table 5

Comparison of Prices per Kilogram of Environmental Goods for Exports and Imports (in CZK)

\begin{tabular}{|l|r|r|r|c|}
\hline Environmental goods for: & \multicolumn{1}{|c|}{$\begin{array}{l}\text { Imports } \\
1993\end{array}$} & $\begin{array}{l}\text { Exports } \\
1993\end{array}$ & $\begin{array}{c}\text { Imports } \\
2002\end{array}$ & $\begin{array}{c}\text { Exports } \\
2002\end{array}$ \\
\hline A1 air pollution control & 197.37 & 10.33 & 22.83 & 26.13 \\
\hline A2 waste water management & 64.92 & 21.19 & 40.71 & 39.86 \\
\hline A3 solid waste management & 95.38 & 25.05 & 151.24 & 66.41 \\
\hline A4 remediation and clean-up & 262.92 & 217.28 & 636.33 & 438.68 \\
\hline A5 noise and vibration abatement & 305.05 & 223.38 & 196.42 & 269.32 \\
\hline A6 environmental monitoring & $1,954.20$ & 51.64 & $2,137.27$ & 733.91 \\
\hline
\end{tabular}

Source: Data of the Statistical Department, the Ministry of Industry and Trade of the CR.

The highest difference in technological features of environmental goods, in terms of price per kilogram, unfavourable for the Czech Republic, can be found in the solid waste management goods, remediation and cleaning goods and, most importantly, in the environmental monitoring instruments. On the other hand, the price per kilogram of the noise and vibration abatement goods on exports is favourable for the Czech Republic.

\section{Analysis of Environmental Goods Customs Ta- riffs in the Czech Republic}

Tariffs represent one of the key economic tools of the foreign trade policy. Unlike the trade policy overall tools, tariffs may selectively enhance development of certain market segments, or, release competition on such markets. Along these lines and 
in the interests of environmental protection both in the advanced and developing countries the WTO member countries decided, in March 2002 to make use of this trade policy tool and engage in negotiations for "reduction or, where appropriate, elimination of tariffs and non-tariff barriers with regard to the environmental goods" (see paragraph 31(iii), Doha Declaration).

With regard to the environmental goods, as a sub-category of industrial products, the key trends apply generally in liberalised market access of industrial products. Further improvement of this liberalization has been importantly aided by the Uruguay Round of the multilateral trade negotiations in which the advanced and developing countries agreed to significantly increase of their imports of industrial products whose tariff rates are bound and to reduce the rates of their own tariffs.

I have used several indicators below to describe the achieved level of liberalization of trade in environmental goods in the Czech Republic.

The first indicator is the share of bound tariffs on environmental goods in the total number of the tariffs. It should be noted in advance in this connection that the Czech Republic, identically to e.g. the U.S. and the EU, ranks among the countries that have adopted bound tariffs (i.e. contract rates of duty) for all tariff lines of industrial articles. From transition economies, the same policy has been adopted also by the Slovak Republic, while the share of bound-tariff lines in the overall amount of the industrial articles tariff lines is only somewhat less in Poland (95.8\%) and Hungary $(95.4 \%)$. Typically for most of the developing countries, on the contrary, is a low proportion of bound-tariff lines of industrial articles (such as Sri Lanka $8 \%$ and Cameroon $0.10 \%$ ) (see Market Access..., 2001).

Commitments undertaken by the Czech Republic with regard to the bound customs tariffs on industrial articles are fully reflected also in the environmental goods analysis.

Table 6

Share of Bound-Tariff Lines of Environmental Goods in the Czech Republic

\begin{tabular}{|l|c|c|}
\hline $\begin{array}{l}\text { Number of tariff lines of environmental } \\
\text { goods (EG) }\end{array}$ & No. of EG tariff lines & $\begin{array}{l}\text { Share of bound-tariff } \\
\text { lines in total No. of } \\
\text { EG tariff lines (in \%) }\end{array}$ \\
\hline Total environmental goods & 161 & 100 \\
\hline of which, goods for: & 27 & 100 \\
\hline A1 air pollution control & 68 & 100 \\
\hline A2 waste water management & 19 & 100 \\
\hline A3 solid waste management & 3 & 100 \\
\hline A4 remediation and clean-up & 3 & 100 \\
\hline A5 noise and vibration abatement & 21 & 100 \\
\hline A6 environmental monitoring, analyses etc. & 20 & 100 \\
\hline B,C - other & & \\
\hline
\end{tabular}

Source: Data of the Czech General Customs Office.

All environmental goods tariff lines are subject to bound tariffs in the Czech Republic. Their further features include their tying to the applied MFN (most-favou- 
red-nation) rate. By this, transparency of trade transactions gets significantly improved for all potential exporters of this type of goods.

Another widely recognised important indicator of the country's degree of openness to trade is represented by the share of duty free tariff lines in the total number of the industrial tariff lines. In advanced countries, the indicator moves along a comparatively broad range (e.g. $17.2 \%$ in Switzerland, $26.9 \%$ in EU, $39.4 \%$ in the U.S. and $47.4 \%$ in Japan). Out of the transition economies, the highest degree of openness towards international trade (as measured by this indicator) is recorded by the Czech Republic and Slovak Republic (14.0\%), followed by Hungary at a small distance $(10.4 \%)$. Poland, on the other hand, has opened but a very little the trade in industrial products $(2.2 \%)$. It should be noted, though, that all Latin American countries (except for Brazil) show this ratio at the zero value (see Market Access..., 2001).

More aggregated information has been offered by a WTO study (see Bacchett, Bor, 2003) that has analysed the situation in 71 WTO member states who have a share of $80 \%$ in the overall worldwide imports of industrial products. The study results have documented that only approx. $6 \%$ out of the total amount of industrial tariff lines are contractually duty free, while they cover one third of the value of the global trade in industrial products.

Following Table 7 provides information on the share of duty free tariff items in the total number of environmental goods tariff items in the Czech Republic (2003).

Table 7

Share of Duty Free Tariff Lines of Environmental Goods in the Czech Republic

\begin{tabular}{|l|c|c|c|c|}
\hline $\begin{array}{l}\text { Number of tariff lines of environmental } \\
\text { goods (EG) }\end{array}$ & $\begin{array}{l}\text { Duty free } \\
\text { bound }\end{array}$ & $\begin{array}{l}\text { Duty free } \\
\text { bound }\end{array}$ & $\begin{array}{l}\text { Duty free } \\
\text { non-bound }\end{array}$ & $\begin{array}{l}\text { Duty free } \\
\text { non-bound }\end{array}$ \\
\hline Total environmental goods (161) & 19 & 11.8 & $/$ & Number \\
\hline of which, goods for: & & & & \\
\hline A1 air pollution control (27) & 1 & 3.7 & $/$ & $/$ \\
\hline A2 waste water management (68) & 6 & 8.8 & $/$ & $/$ \\
\hline A3 solid waste management (19) & $/$ & & $/$ & $/$ \\
\hline A4 remediation and clean-up (3) & $/$ & $/$ & $/$ & $/$ \\
\hline A5 noise and vibration abatement (3) & $/$ & $/$ & $/$ & $/$ \\
\hline A6 environmental monitoring, analyses (21) & 8 & 38.1 & $/$ & $/$ \\
\hline B,C - other (20) & 4 & 20.0 & $/$ & $/$ \\
\hline
\end{tabular}

Source: Data of the Czech General Customs Office (duty free non-bound tariffs are not used in the Czech Republic).

It follows from data in the table that the share of the duty free tariff lines in the overall number of the environmental goods tariff lines in the Czech Republic amounts to practically $12 \%$. The Czech Republic, in the environmental goods area, has been the most widely open to the imports of instruments for the environmental condition monitoring (these include e.g. instruments for measurements of liquids and gases, chromatographs, spectrometers, apparatuses for physical and chemical analyses, optical devices, etc.). A duty free tariff exists under the "Other" item e.g. for 
photosensitive semiconductor devices, including solar cells in that number; for ion exchangers based on polymers; or for mineral waters and carbonated waters.

The degree of openness of the Czech Republic to the environmental goods imports (as measured by this indicator) as almost 4 times higher than a similar indicator for the EU (3.2\%) and comes close to the same indicator for Canada (13.7\%). On the other hand, it is 3 times lower compared to a similar indicator for the U.S. $\left.(34.7 \%) .{ }^{9}\right)$

Another feature providing description of an overall level of tariff protection with regard of environmental goods is defined as the average bound customs tariffs on environmental goods and their separate subgroups. While several traditional procedures exist for allocating relevant "weights" to the tariffs at calculation, the table below has employed the simple average of the bound tariffs. The simple average allocates the same weight to each tariff line of the environmental goods and therefore does not require any other data from trade or production. The reason for choosing the simple average method for the bound tariffs has been an opportunity to make comparisons to certain other available information.

Table 8

Simple Average of Bound Tariffs for Environmental Goods (2003, in \%)

\begin{tabular}{|l|l|}
\hline Goods & 4.0 \\
\hline Total environmental goods & \\
\hline of which, goods for: & 3.6 \\
\hline A1 air pollution control & 3.9 \\
\hline A2 waste water management & 4.4 \\
\hline A3 solid waste management & 2.9 \\
\hline A4 remediation and clean-up & 4.0 \\
\hline A5 noise and vibration abatement & 1.4 \\
\hline A6 environmental monitoring, analyses etc. & 7.1 \\
\hline B, C - other goods & \\
\hline
\end{tabular}

Source: Calculation has been based on the data of the General Customs Office.

The simple average of bound tariffs for environmental goods in the Czech Republic amounts to $4.0 \%$. The leading advanced QUAD countries (i.e. Canada, the EU, Japan and the U.S.) show a lower value of the indicator (2.5\%). As a useful illustration, there are added that e.g. a selected group of developing countries (Argentina, Brazil, Chile, Malaysia, India, Indonesia and Thailand) record the average tariffs for environmental goods at $28.7 \%$ (see Environmental Goods..., 2001).

The average bound tariff indicators for separate groups of environmental goods may be used also to illustrate gradual liberalization of trade on this special market segment. It is described by reduction of the average tariff burden of environmental

9) Data for the EU, the U.S. and Canada have been calculated using Appendix 3 "Bound and Applied Tariffs on Environmental Goods in 14 Markets" that has been based on the tariff databases of the UNCTAD and WTO (see Environmental Goods and Services..., 2001). 
goods over the period from the year 1996 to the end of Uruguay Round of trade negotiations. The Table 9 provides a comparison of the load in the leading advanced QUAD countries and the Czech Republic.

Table 9

Comparison of Average Tariffs Levels for Environmental Goods in Advanced Countries (QUAD) and Czech Republic (ad valorem, in \%)

\begin{tabular}{|l|c|c|c|c|}
\hline \multirow{2}{*}{} & \multicolumn{2}{|c|}{ QUAD } & \multicolumn{2}{c|}{ CR } \\
\cline { 2 - 5 } & $\begin{array}{l}\text { Bound tariff, } \\
\text { end of UR }\end{array}$ & $\begin{array}{l}\text { Applied tariff, } \\
\text { MFN 1996 }\end{array}$ & $\begin{array}{l}\text { Bound tariff, } \\
\text { end of UR }\end{array}$ & $\begin{array}{l}\text { Applied tariff, } \\
\text { MFN 1996 }\end{array}$ \\
\hline $\begin{array}{l}\text { Total environmental goods } \\
\text { of which, goods for: }\end{array}$ & 2.5 & 3.4 & 4.0 & 5.5 \\
\hline A1 air pollution control & 2.0 & 2.4 & 3.6 & 4.6 \\
\hline A2 waste water management & 2.6 & 3.2 & 3.9 & 4.8 \\
\hline A3 solid waste management & 3.0 & 4.0 & 4.4 & 5.6 \\
\hline A4 remediation and cleanup & 2.6 & 3.0 & 2.9 & 3.7 \\
\hline A5 noise and vibration abatement & 2.0 & 2.1 & 4.0 & 5.0 \\
\hline A6 environmental monitoring, analyses & 1.4 & 2.5 & 1.4 & 2.9 \\
\hline B,C - other & 3.0 & 4.1 & 7.1 & 9.3 \\
\hline
\end{tabular}

Source: for the QUAD countries, the data have been adopted (see Environmental Goods..., 2001), for the Czech Republic they have been calculated based on the data of the General Customs Office.

The data in the Table 9 document that the average of tariffs levels for environmental goods dropped, at the end of the Uruguay Round of the trade negotiations, by $40 \%$ in the leading advanced countries (QUAD), while they dropped only by approx. $28 \%$ in the Czech Republic.

A comparison of the average bound tariff level on environmental goods $(4.0 \%)$ to a similar indicator for the industrial products $(4.3 \%$ in the Czech Republic) indicates basically a negligible difference in this case. However, the Czech Republic (the same as the Slovak Republic), in terms of its recorded average of bound tariffs levels for industrial products comes the closest to the value of the indicator in the EU $(4.1 \%)$. The other transition economies show a distinctly higher average of bound tariffs levels for industrial products (such as $7.4 \%$ for Hungary, $10.4 \%$ for Poland and even $30.8 \%$ for Rumania). A high average of bound tariffs levels for industrial products is typical of many developing countries (such as $58.7 \%$ for India) (see Market Access..., 2001).

Average tariffs levels for industrial articles differ significantly for separate countries by industrial product category (they amount to the highest values for "textiles and clothing" in most countries, including the Czech Republic).

The tariff burden on environmental goods may be examined also from the perspective of tariff dispersion. It means in general that the economic inefficiency of the tariff regime increases with the considerable dispersion of tariffs, i.e. if their structure includes both a high number of tariff peaks and of very low values. A comparatively uniform structure of tariffs is more transparent and, from the administrative point of view, easier to manage, while it also creates less room for tariff escalation. 
Tariff dispersion may be expressed in several ways. The first one is a calculation of the standard deviation. That represents an absolute dispersion of the tariff levels around their average value. ${ }^{10)}$ In other words, the standard deviation shows how separate environmental goods tariffs levels are "distributed" in relation to the average. The lesser the standard deviation, the more representative feature may the average be deemed.

Table 10

Standard Deviation in Bound Tariffs for Environmental Goods in the Czech Republic

\begin{tabular}{|l|c|c|}
\hline & Standard deviation & $\begin{array}{c}\text { Standard deviation, } \\
\text { excl. extreme value }\end{array}$ \\
\hline Total environmental goods & 6.08 & 1.93 \\
\hline of which, goods for: & & \\
\hline A1 air pollution control & 1.42 & \\
\hline A2 waste water management & 1.81 & \\
\hline A3 solid waste management & 1.29 & \\
\hline A4 remediation and clean-up & 1.38 & \\
\hline A5 noise and vibration abatement & 0.85 & \\
\hline A6 environmental monitoring & 1.29 & 2.57 \\
\hline B,C - other & 16.21 & \\
\hline
\end{tabular}

Source: Calculation with help of an expert from Czech Statistical Office based on the data of the General Customs Office.

There is one unique and utterly extreme figure among the Czech tariffs rate for environmental goods: the duty of $77 \%$ on the non-methylated ethylalcohol with alcohol volume of $80 \%$ and over. The rate has been significantly affecting the value of the standard deviation for its "other" subsegment as well as the total deviation. That is why a variant calculation excluding this extreme item has been also prepared for the two instances. Basing on that assumption, the standard deviation comes out very small compared to the amount of the tested values. The standard deviation calculation, however, supports a highly representative rate of averages for the most frequented lines of environmental goods (A1 - A5).

Another tariff dispersion indicator suitable for performing an analysis of environmental goods consists in the incidence of "tariff peaks". Tariff peaks are understood to include those exceeding the determined reference level. The OECD documents distinguish between "national" peaks where the reference level is represented by the threefold national average tariff and the "international" peak with the reference level set at $15 \% .{ }^{11)}$

10) The standard deviation is the square root of the dispersion, while the dispersion is the arithmetic mean of square roots of deviations of a character from the arithmetic mean.

11) Certain other surveys mention $10 \%$ reference level, and some other ones even $20 \%$ reference level. 
The Table 11 is setting out a calculation of the tariff dispersion of environmental goods in the Czech Republic including both the "national" and "international" peaks.

Table 11

Tariff Dispersion in Environmental Goods in the Czech Republic (2003)

\begin{tabular}{|l|c|c|c|}
\hline $\begin{array}{l}\text { Number of tariff lines of } \\
\text { environmental goods }\end{array}$ & $\begin{array}{c}\text { 3-fold } \\
\text { average }\end{array}$ & $\begin{array}{c}\text { Number of tariff lines with rate } \\
\text { of duty exceeding 3-fold average }\end{array}$ & $\begin{array}{c}\text { Number of tariff lines with rate of } \\
\text { duty exceeding 15 \% }\end{array}$ \\
\hline Total environmental goods (161) & 12.0 & 1 & 1 \\
\hline of which, goods for: & & 0 & 0 \\
\hline A1 air pollution control (27) & 10.8 & 0 & 0 \\
\hline A2 waste water management (69) & 11.7 & 0 & 0 \\
\hline A3 solid waste management (19) & 13.2 & 0 & 0 \\
\hline A4 remediation and clean-up (3) & 8.7 & 0 & 0 \\
\hline A5 noise and vibration abatement (3) & 12.0 & 0 & 0 \\
\hline A6 environmental monitoring (21) & 4.2 & 1 & 1 \\
\hline B,C - other (20) & 21.3 & 0 & 0 \\
\hline
\end{tabular}

Source: Calculation based on the data of the General Customs Office.

The tariff dispersion in environmental goods in the Czech Republic, evaluated using the above indicators, is but a minimum one, as the share of lines exceeding national and/or international peaks in the total number of tariff lines of environmental goods is $0.6 \%$ in either case. The only deviation is the already mentioned tariff line "Ethylalcohol" with the rate of $77 \%$ (the rate amounted even to $86.1 \%$ in 1996). Otherwise, the highest tariff rate for environmental goods was $9 \%$ in 2003 (only for a single tariff line), while 15 tariff lines fell within the interval $6-7 \%$. In fact, an overwhelming majority of tariff lines of environmental goods is subject to the rate of duty up to $5 \%$.

A comparison may only be based on similar indicators calculated for industrial products. According to the WTO study (see Market Access..., 2001), the proportion of tariff lines with the duty in excess of the threefold average is $1.2 \%$ for the Czech Republic (2.6\% in the EU and $7.5 \%$ in the U.S.). The share of tariff lines with the duty in excess of $15 \%$ amounts to $0.9 \%$ in the CR $(1.5 \%$ in the EU and $3.5 \%$ in the U.S.). The tariff dispersion has been also considerably affected by different tariffs rate of the key industrial product categories. In the leading advanced countries, the average bound tariffs rate, e.g. for the textiles and clothing, are materially higher as compared to the tariffs rate for the other categories, which resultantly increases the tariff dispersion degree. The Czech Republic, identically to the other transition economies, records in the industrial product group the highest tariff rate for the category of "transport equipment" (12.3\%), while the share does not exceed $3 \%$ with any other category. 


\section{Conclusion}

The total trade balance for environmental goods has been negative throughout the whole period under review: the Czech Republic's environmental goods imports have exceeded exports. In 2002, the share of environmental goods amounted to $6.4 \%$ in the total Czech imports and $5.1 \%$ in the total Czech exports (in value terms). A comparison of the price per kilogram of environmental goods is unfavourable for the Czech Republic both for imports and exports, except for the noise and vibration abatement goods, and indicates an existing unutilised potential for improving the technological level of relevant products. The largest share in both the environmental goods imports and exports has been held by the waste-water management goods. The air pollution control goods have been the second strongest imports commodity, while the noise and vibration abatement goods have asserted themselves quite dynamically in the exports.

The overall dynamics of the foreign trade in environmental goods has been determined by the trade with advanced countries, specifically EU Members. An dominant position of Germany, both in the imports and exports (40\%), makes the Czech Republic excessively dependent, for this market segment, on the business cycle in Germany. From the transition economies, the Czech Republic has been maintaining relevant trade within the environmental goods segment only with Slovakia and Poland. The Czech trade in environmental goods with developing countries has been marked by absolutely contradictory tendencies: only a very low increase of environmental goods exports in the developing countries has been noted, it grew by $37 \%$ between 1993 and 2002. In 1993, Czech imports of environmental goods from developing countries were practically negligible $(0.3 \%)$, and while this share grew more than sixfold in 2002, these imports' amount is still very low.

A high degree of openness of the Czech Republic towards imports of environmental goods has been supported by the following descriptions: all the Czech Republic's tariff lines for environmental goods are bound at the level of the applied most-favoured-nation rate; around $12 \%$ of the tariff lines for environmental goods are duty-free - which is 4 times the EU rate, the simple average of bound customs tariffs on environmental goods imported to the Czech Republic is $4.0 \%$, an overwhelming majority of tariff lines on environmental goods are subject to duties of $5 \%$ or less. Tariff dispersion in environmental goods, measured by the share of rariff lines with duties more than three times the average and with duties above $15 \%$, is just $0.6 \%$ for both options.

\section{References}

Bacchett, M., Bor, B. (2003), "Industrial Tariff Liberalization and the Doha Development Agenda." World Trade Organization.

"Environmental Goods and Services, the Benefits of Further Global Trade Liberalization" (2001). Paris, OECD.

"Environmental Goods: A Comparison of the APEC and OECD Lists" (2003). Paris, OECD, COM/ENV/ TD(2003)10/Final, 29 April, 2003.

"Market Access: Unfinished Business. Post-Uruguay Round Inventory and Issues" (2001). WTO, Special Studies 6.

Nešvera, V., Kubišta, V. (2001), "Czech Republic's Position in International Trade" (in Czech). Prague, University of Economics.

"Report on the Environment in the Czech Republic in 2001" (in Czech) (2002). Prague, Ministry of Environment of the CR.

"The Environmental Goods and Services Industry, Manual for Data Collection and Analysis" (1999). Paris, OECD, Eurostat. 